\title{
The Word of Islam
}

\section{By John Alden Williams, ed., Austin: University of Texas Press, 1994, 232 pp.}

Anthologies have been known to string together mangled pieces of writing in ways reminiscent of a tanner's drying rack or a horror film studio's collection of gory rubber limbs and masks. But there seems to be little disparity, disjunction, or morbidity in Professor Williams's book, his second major attempt to "let Islam speak for itself." The first was the seminal Islam, which came out in 1961 and broke new ground as well as a few fetters. The new endeavor sets out to offer the faith (and the culture associated with it) a better-tuned mike at a time when the dominant world media is busy blackening its name and reputation. Of course, even with the best of intentions, the task of introducing Islam in capsule form, its own essential simplicity notwithstanding, is both impossible and unfair. The editor, however, is alive to the predicament and recognizes that Islam, like "every great religion," is akin to an "ocean, with many bays, inlets, and unplumbed areas." In essence, "we can only come to it, smell it, taste it, touch it, observe what thrives there, and listen to its many moods."

The sentiment may betray an outsider's perspective, but it is refreshingly honest and respectful. Moreover, it is the product of a long engagement with and pondering over such pedagogic issues as "how one may most effectively and practically study Islam." No short-cut, not even a good anthology, is recommended. Rather,

read the texts which convey its tradition in as wide a range as one can. An original text is worth more than many words of explanation. Go to the sources and listen to voices that have rung with authority for generations, that Muslims have recognized, and use only enough introductory material to set the voice in its context.

Some may argue whether presenting translated extracts from the basic Islamic canon to a modern and arguably hostile or misinformed audience requires ample commentary. But the editor, in addition to his main concern of presenting that canon in meaningful digest form, takes care to demarcate the territory between ancient and modern. Be that as it may, to a large degree he succeeds in choosing (and translating) highly pertinent and interrelated excerpts as well as in introducing them with conciseness and clarity, erudition and sympathy. 
Indeed, the editor questions the effective worth of a book about a religion that does not allow its adherents to say, "Yes, it is like that!" Traumatized or simply put off by fake or lopsided representations of Islam from within and without, a sympathetic reader cannot but take warmly to the declared intention and identify, in varying degrees, with the overall product.

Inevitably there will be those who hate to see "sectarian movements" represented and so argue for a pristine Islam untainted by political division and historical practice. But that would be unrealistic and would detract from the objectivity and representativeness of the selection, itself comprising, besides an excellent introduction and a well-informed afterward (entitled "Islam Today"), selections from the Qur'an, the hadith literature, the Shari'ah, fiqh, Sufism, kaläm, and the various madhähib. The extracts' breadth and variety, along with the shrewd and at times skeptical commentary, help to give the anthology a sense of balance as well as a dynamism and roundedness emblematic of the Islamic experience itself.

But there is no lack of tact. The anthology is introduced fittingly by Sūrat al Fātihah, "recited every time Muslims begin their prayer and when any new thing is to be undertaken." The brief but meritorious introduction presents the book's rationale and methodology and offers insightful and needed explanations of such key Arabic words as "Allah" (i.e., "Non-Muslims should not be given the misleading impression so many have received in the past that Muslims do not worship God, but something else called (Allah"). The exercise, more happily than not and except in the few cases where the translations are not the editor's, is pursued throughout and results, at times, in a crop of very fresh interpretations of classical terms. Regrettably, these are not grouped in a glossary. There is also the astute use of gender-inclusive language (i.e., "Islam is the religion of women as well as men, and translated texts should not give the impression that it is only intended for males"). Introductory notes to the selections work quite well within the chosen compression and are, as a rule, both knowledgeable and fair. One example is the note introducing the Qur'anic passages from Sürat al A'raf:

The story of the Garden of Eden is very like that contained in the Book of Genesis, but there is no doctrine of original sin in Islam. The fall of Adam and Eve is seen as an error in judgment, not as a taint in their descendants. From Adam's creation, humankind has made a contract to serve God-a unique glory and burden, for which it is weak, but not impotent. 
Obviously, an anthology is very much a personal offering, a bouquet influenced in its composition, even its wrapping, by the offerer's likes and dislikes as well as his or her level of awareness and responsibility. Inevitably, there will be choices to which others may object, omissions that many will lament, translations whose inaptness or boldness scholars may censure, and statements that are not rigorously supported by documentation, an abundance of which was perhaps deemed by Williams as being too cumbersome for a publication striving to be informative, readable, and compact. There may be people who will see the whole exercise as a byproduct of a consumeristic, "American," or even orientalist tendency to market a product or offer policy makers a clue as to what makes Islam and Muslims tick. However, this can be taken too far and may verge on the paranoiac or xenophobic.

There is no denying that Islam needs to be presented equitably (never mind attractively) to modern readers at both the popular and the specialized levels. Hence the declared intention that it "behooves non-Muslims to understand the terms in which Islam thinks and to communicate with Muslims today" should be taken to mean what it says and, in an overwhelmingly fair and evenhanded context, must be encouraged. Mainstream Islam is an open creed and has no hidden text or hidden agenda. Indeed, its claim to eternity is that it set out from the very beginning to forestall, and then to break down, such barriers as have been erected by the priesthood and ethnocentricity, and to take the Word-the complete, freeborn, unadulterated, but also continually evolving and expanding Word-to everyone, liberating in the process both the mind and the imagination. Thus any honest perusal or scrutiny of its corpus (a corpus not always reinforced or animated by happy application) should not make the zealot cringe or induce him/her to invoke the good old conspiracy theory. The Qur'an addresses itself to the whole of humanity and invites humanity in its entirety to respond, preferably with gentle and rational argument. Later suspicion, nervousness, hypersensitivity, and withdrawal more often than not have been symptoms of a steady erosion of selfconfidence and a pathological reluctance to take the faith beyond safe and secure borders.

The Prophet's bequest (or living gift) should not be turned (however irreverent the metaphor might sound) into a box of sweets or taken as something easy, as is often the case. Rather, as the Qur'an emphasizes repeatedly, it should be seen as a challenge, a gauntlet thrown down to the community, indeed to all of humanity, to improve itself continually without letting go of the ideals of fraternity, compassion, gentleness, fairness, and other virtues. 
This book has its challenging aspects - to both the Muslims and to the hostile, misinformed, or indifferent world that surrounds them and to which they themselves sometimes add territory. Despite that, the book deserves to be celebrated. It may not always elicit the sort of rave (though admittedly generalized) review found here. The present reviewer has just emerged from an academic year in the course of which some seven or eight participants in two locally organized lecture series did their subtlest and crudest best to malign Islam and marginalize its contribution to the past as well as to cast doubt on its fitness to join the league of civilized nations. Indeed, the very term "civilization" was stated bluntly by one as too lofty a term to apply to the society and heritage created by Islam.

Under the circumstances, one was left with a feeling of profound sadness at the intractable bias and the galloping zeal by distinguished academics to pander to the popular penchant for Arab and Muslim bashing - a penchant shaped by the media but also aided and given moral justification by many academics who, for various personal and occupational reasons, seem to be supplanting the old clerics in the unseemly act of inciting hatred and disseminating half-truths while kowtowing to the dominant power of the day. Many of these academics are, of course, staunch secularists, yet the vehemence (sometimes even the phraseology) of their pronouncements reminds one of the medieval polemics against Islam, reasserting the impression that such diatribes are-and have often been-racial in essence and have very little to do with matters of creed and spirituality. One's sadness was always compounded by one's own keen awareness of the near chaos and impotence pervading much of what is termed the Muslim world-a near chaos and impotence manifested, among other things, in both extreme passivity and extreme violence, along with the inability to give adequate modern expression to the Islamic message, let alone understand and deal with the outside world creatively.

So it has been most refreshing to see Williams speak of Islam as a "great religion," its civilization as "one of the world's great civilizations, producing art, architecture, literature, and material culture which have been the envy and admiration of the world," that "no world religion has been more successful than Islam in teaching mystical religion to the masses," that "Muslims have been generally very tolerant of differences of opinion," that the "odes of Ibn al Farid can be as lovely as poems by Shelley or Keats" (slightly patronizing this one?), or that "for nearly a thousand years," the Muslims "had usually demonstrated an easy sort of superiority over the West, in terms of seapower, productivity, trade, gracious living, science, and intellectual achievements." 
Nor is such vindication accorded to the classical period alone. In the brisk and functional afterward, an overview of Islam in the modem period is offered. In this, we read that the "western world, particularly the United States, has been slow to grasp how much the world has changed." Various cases for Muslim grievances against colonial and imperialist power and the media, together with the Muslims' own views, aspirations, and legitimacy within a modern world, are reated with insight and compassion, though not without critical acumen.

The book is certainly no unqualified apologia or "golden treasury" of the best the Islamic canon can offer in digest form. One can argue for the superiority or validity of other would-be extracts and judgments here and there. But, on the whole and within the strict, albeit handy, space of 232 pages, the editor generally lives up to his promise to "let Islam's word come through." Of course, there will be those who will deem (and condemn) the book as too sympathetic. But theirs will be the voice of prejudice quavering in the face of the erudition and sense of balance permeating the book. As John Esposito has shown, both amply and recently, good scholarship will weather any stom raised for spite or vested interests. And like Esposito's, this work is destined to be treated as a pioneer and a classic in its field. The readership it targets (and deserves) is quite broad. Sustained, perhaps sometimes unconsciously, by the metaphor of the ocean, it offers a highly readable, lively, and proportionate examination of the Islamic canon and its various internal currents. The overall impression it helps give is not of a stultified or self-enclosed creed or culture, but of one characterized from the outset by dynamism and a vigorous debate with itself and the "other"- surely a mark of health and vitality.

Riad Nourallah

Darwin College Cambridge, UK 